\title{
Penerapan Model Pembelajaran Berbasis Proyek Bermedia Audio Visual Dalam Pembelajaran Menulis Teks Cerita Fantasi Pada Kelas VII SMP
}

\author{
Abdul Rozak ${ }^{1)}$, Juwanda ${ }^{2)}$ \\ Abdurrozak58@gmail.com ${ }^{1)}$,juwandacrb165@gmail.com ${ }^{2)}$ \\ Universitas Swdaya Gunung Jati ${ }^{12)}$
}

\begin{abstract}
Abstrak. Penelitian ini bertujuan menjelaskan proses pembelajaran, kefektifan pembelajaran, dan karya siswa berupa teks cerita fantasi dengan menggunkan model pembelajaran berbasis proyek bermedia audio visual pada siswa kelas VII SMP Negeri 1 Pangenan. Teknik pengumpulan data yang penulis gunakan adalah tes dan observasi. Data yang diperoleh yaitu berupa hasil memproduksi teks cerita fantasi siswa. Data itu kemudian diolah dengan menggunakan uji statistik uji $t$-test. Berdasarkan hasil pengolahan data diperoleh nilai $\mathrm{T}_{\text {hitung }} 2,67$ dan $\mathrm{T}_{\text {tabel }} 2,9$. Hal ini menunjukan bahwa penerapan model pembelajaran berbasis proyek bermedia audio visual dalam pembelajaran teks cerita fantasi pada siswa kelas VII SMP Negeri 1 Pangenan berlangsung efektif. Sementara itu, hasil dari observasi, data diperoleh dari proses pembelajaran siswa dalam menulis teks cerita fantasi menggunakan model pembelajaran berbasis proyek bermedia audio visual. Dari data hasil observasi proses pembelajaran teks cerita fantasi dengan menggunkan model pembelajaran berbasis proyek bermedia audio visual sudah berjalan dengan baik, dalam hal ini sudah adanya interaksi antara siswa dengan guru, serta siswa dengan siswa lainnya. Pembelajaran teks cerita fantasi dengan menggunakan model pembelajaran berbasis proyek bermedia audio sudah efektif. Hal ini ditunjukan dengan adanya peningkatan hasil tes antara nilai tes awal dengan nilai tes akhir yaitu dengan rata-rata tes awal sebesar 69 dan tes akhir sebesar 80,4. Hasil karya tulis siswa dalam pembelajaran menulis teks cerita fantasi dengan menggunakan model pembelajaran berbasis proyek bermedia audio sudah sangat baik. Hasil tulisan siswa pada tes akhir sudah sesuai dengan struktur dan kaidah kebahasaan teks cerita fantasi.
\end{abstract}

Kata Kunci : model berbasis proyek, media audio visual, teks cerita fantasi.

\section{Pendahuluan}

Pembelajaran bahasa Indonesia memiliki tujuan akhir dalam pembelajarannya, yaitu memiliki aspek keterampilan berbahasa. Ada beberapa aspek keterampilan berbahasa yang harus dikuasai oleh siswa. Menurut Tarigan, (2008) Keterampilan berbahasa mencakup empat aspek, yaitu keterampilan mendengarkan, keterampilan berbicara, keterampilan membaca, dan keterampilan menulis. Menulis merupakan bagian dari aspek kebahasaan yang harus dimiliki oleh setiap siswa. Sebagai bagian dari keterampilan berbahasa, menulis berkaitan erat dengan aktivitas berpikir dan pengungkapan imajinasi perasaan atau ide seseorang dalam bentuk tulisan yang indah.

Sutari (1997) menjelaskan bahwa menulis adalah aktivitas yang bukan sekedar menggambar huruf-huruf, tetapi ada pesan yang dibawa oleh penulis melalui gambar-gambar huruf-huruf tersebut, yaitu karangan-karangan sebagai ekspresi pikiran, gagasan, pendapat, pengalaman yang disusun secara sistematis dan logis. Dengan adanya keterampilan menulis, selain untuk mengungkapkan gagasan, perasaan, pikiran siswa diharapkan mampu menuangkan imajinasinya dalam bentuk tulisan. Salah satu bentuk tulisannya adalah teks cerita fantasi. Menurut Kemendikbud. (2016) Teks fantasi atau cerita fantasi adalah cerita yang terdapat unsur 
magis, misteri, kesaktian, atau hal supranatural yang lain. Teks cerita fantasi memberdayakan percampuran latar cerita dengan memfantasikan latar masa lalu, masa kini, dan masa mendatang. Dalam teks cerita fantasi tokoh-tokohnya memiliki kekuatan yang tidak dimiliki oleh manusia biasa, dan menggunakan beberapa latar. Struktur teks cerita fantasi terbagi menjadi tiga bagian, yaitu orientasi, komplikasi, dan resolusi.

Pembelajaran menulis teks cerita fantasi di tingkat SMP/MTs kelas VII dalam kurikulum 2013 terdapat pada Kompetensi Dasar (KD) 4.4 yaitu Menyajikan gagasan kreatif dalam bentuk cerita imajinasi secara lisan dan tulis dengan memperhatikan struktur, penggunaan bahasa, atau aspek lisan.

Berdasarkan hasil observasi yang dilakukan penulis di lapangan, banyak peserta didik yang masih kesulitan cara menulis sebuah teks. Kesulitan yang dialami oleh peserta didik salah satunya adalah kurangnya ide yang dimiliki untuk dituangkan ke dalam bentuk tulisan menjadi sebuah karya. Selain itu, Kurangnya pengalaman peserta didik dalam kegiatan kepenulisan kreatif juga memicu kesulitan peserta didik dalam membuat sebuah karya tulis. Penerapan Kurikulum 2013 dalam pelaksanaan pendidikan formal di sekolah, menjadikan keterampilan menulis sebagai keterampilan utama dalam pembelajaran bahasa Indonesia. Maka dari itu, pembelajaran menulis perlu dikelola dengan menerapkan model atau metode pembelajaran yang relevan dengan materi yang akan disampaikan. Dalam kurikulum 2013 pun telah terdapat beberapa pendekatan, dan model yang dapat diterapkan didalamnya, salah satunya adalah Model Pembalajaran Berbasis Proyek. Menurut Abidin, (2014) bahwa Model Pembelajaran Berbasis Proyek adalah model pembelajaran yang secara langsung melibatkan siswa dalam proses pembelajaran melalui kegiatan penelitian untuk mengerjakan dan menyelesaikan suatu proyek pembelajaran tertentu. Selain itu, peran media dalam sebuah pembelajaran sangat menentukan. Gerlach dan Ely (Hamdani, 2011) mengatakan bahwa media apabila dipahami secara garis besar adalah manusia, materi atau kejadian yang membangun kondisi yang membuat siswa mampu memperoleh pengetahuan, keterampilan, atau sikap. Dalam pengertian ini, guru, buku teks, dan lingkungan sekolah merupakan media. Salah satu jenis media yang dapat digunakan dalam pembelajaran adalah media audio visiual. Asyhar (2011) mendefinisikan bahwa media audio visual adalah jenis media yang digunakan dalam kegiatan pembelajaran dengan melibatkan pendengaran dan penglihatan sekaligus dalam satu proses atau kegiatan.

Berdasarkan latar belakang di atas penulis tertarik untuk melakukan penelitian mengenai "Penerapan Model Pembelajaran Berbasis Proyek Bermedia Audio Visual dalam Pembelajaran Menulis Teks Cerita Fantasi pada Kelas VII SMP.

\section{Metode}

Metode penelitian yang digunakan penulis yaitu metode eksperimen semu (quasi experiment). Penggunaan metode eksperimen semu ini bertujuan untuk mendapatkan hasil belajar siswa. Metode eksperimen semu ini memiliki kelompok kontrol. Akan tetapi, kelompok kontrol tersebut tidak dapat berfungsi sepenuhnya untuk variabel-variabel luar yang mempengaruhi pelaksanaan penelitian eksperimen. Sugiyono (2017)

Penggunaan metode penelitian eksperimen mengharuskan adanya perlakuan khusus terhadap objek penelitian atau variabel yang dilihat paling dominan. Tujuannya adalah untuk 
mengetahui pengaruh perlakuan yang diterapkan di kelas eksperimen dan ada atau tidaknya perbedaan antara kelas ekspermen dan kelas kontrol.

Perlakuan yang diterapkan di kelas eksperimen adalah menggunakan model pembelajaran berbasis proyek bermedia audio visual sedangkan kelas kontrol mendapat perlakuan berupa penggunaan model pembelajaran discovery learning. Penelitian menggunakan metode eksperimen ini, bertujuan untuk menguji ada tidaknya sebab akibat dari perlakuan model berbasis proyek bermedia audio visual terhadap pembelajaran memproduksi teks cerita fantasi.

\section{Hasil dan Pembahasan}

Bagian bab ini, penulis menguraikan dan menggambarkan data hasil penelitian yang berjudul "Penerapan Model Berbasis Proyek Bermedia Audio Visual dalam Pembelajaran Menulis Teks Cerita Fantasi pada Siswa Kelas VII SMP Negeri 1 Pangenan Tahun Pelajaran 2019/2020". Berdasarkan judul penelitian tersebut, rumusan masalah yang disusun adalah sebagai berikut; 1) Bagaimana proses pembelajaran menulis teks cerita fantasi dengan menggunakan model pembelajaran berbasis proyek bermedia audio visual? 2) Apakah model pembelajaran berbasis proyek bermedia audio visual dalam pembelajaran menulis teks cerita fantasi efektif? 3) Bagaimana teks cerita fantasi karya siswa?

Berdasarkan hasil pengamatan yang dilakukan selama proses pembelajaran, aktivitas siswa sudah baik. Secara keseluruhan, siswa mengikuti kegiatan pembelajaran menulis teks cerita fantasi dengan aktif dan kreatif. Hal tersebut dapat dilihat pada data hasil observasi selama kegiatan pembelajaran. Siswa mengikuti tiap langkah pembelajaran dengan baik, dengan model pembelajaran berbasis proyek, kegiatan pembelajaran teks cerita fantasi menjadi menyenangkan dan membuat siswa lebih kreatif. Permasalahan yang dikaji dalam model pembelajaran berbasis proyek merupakan yang ditemukan siswa dalam kehidupan sehari-hari, sehingga siswa lebih mudah mendapatkan bahan untuk dijadikan objek menulis teks cerita fantasi dari hasil pengamatan sekitar.

Berdasarkan perhitungan uji statistik uji-t terdapat perbedaan antara hasil tes pembelajaran kelas eksperimen dan kelas kontrol. Hasil perhitungan tersebut adalah $\mathrm{T}_{\text {hitung }}=$ 2,67> $\mathrm{T}_{\text {table }}=2$,9. Berdasarkan hasil tersebut, maka hipotesis kerja $\left(\mathrm{Hi}_{\mathrm{i}}\right)$ diterima dan hipotesis nol (Ho) ditolak. Hal ini menunjukan bahwa pembelajaran yang menggunakan model pembelajaran berbasis proyek bermedia audio visual lebih efektif karena nilai Thitung lebih besar dari nilai Ttable. Artinya, pembelajaran menulis teks cerita fantasi menggunakan model pembelajaran berbasis proyek bermedia audio visual berlangsung efektif.

Berdasarkan tes akhir, siswa dapat membuat tulisan teks cerita fantasi sesuai dengan struktur dan kaidah kebahasaan. Nilai rata-rata kemampuan akhir siswa dalam pembelajaran menulis teks cerita fantasi pada kelas eksperimen yaitu 80,4. Hal ini sudah melebihi nilai Kriteria Ketuntasan Minimal (KKM) yaitu 75.

\section{Simpulan}

Berdasarkan hasil penelitian yang telah dilakukan oleh penulis di SMP Negeri 1 Pangenan yang berjudul "Penerapan Model Berbasis Proyek Bermedia Audio Visual dalam 
Pembelajaran Menulis Teks Cerita Fantasi pada Kelas VII SMP Negeri 1 Pangenan Tahun Ajaran 2019/2020" menghasilkan kesimpulan sebagai berikut.

1. Hasil observasi proses pembelajaran dengan menggunakan model berbasis proyek bermedia audio visual dalam pembelajaran menulis teks cerita fantasi di kelas eksperimen menunjukan bahwa penggunaan model pembelajaran berbasis proyek bermedia audio visual pada siswa kelas VII SMP Negeri 1 Pangenan dapat meningkatkan aktivitas siswa dalam proses pembelajaran. Hal tersebut dapat dilihat dari hasil presentase yang memperoleh nilai rata-rata sebesar 89,22\%. Hal ini tergolong kedalam kategori sangat baik.

2. Penerapan model berbasis proyek bermedia audio visual berpengaruh dan efektif terhadap pembelajaran menulis teks cerita fantasi pada siswa kelas VII SMP Negeri 1 Pangenan. Hal tersebut terbukti dari hasil uji-t bahwa Thitung > Ttabel. Hasil ini dapat disimpulkan bahwa penerpan model berbasis proyek bermedia audio visual berpengaruh dan efektif terhadap pembelajaran menulis teks cerita fantasi pada siswa kelas VII SMP Negeri 1 Pangenan.

3. Hasil karya tulisan siswa kelas VII SMP Negeri 1 Pangenan dalam membuat teks cerita fantasi sudah baik. Hal ini terlihat dari hasil tes akhir kelas eksperimen yan sudah sesuai dengan kriteria penilaian. Pada penulisan judul siswa sudah mampu menuliskan judul sesuai dengan isi teksnya. Dari segi struktur, siswa sudah menuliskannya dengan baik, yaitu orientasi, komplikasi, dan resolusi. Lalu dari segi kaidah kebahasaan siswa sudah menggunakan kaidah kebahasaan sesuai kriteria yang ada dalam penilaian.

\section{Daftar Pustaka}

Abidin , Y. 2014. Desain Sistem Pembelajaran dalam Konteks Kurikulum 2013. Bandung: Refika Aditama

Asyhar, R. 2011. Kreatif Mengembangkan Media Pembelajaran. Gaung Persada (GP) Press Jakarta. Jakarta

Guntur, Tarigan. 2008. Menulis sebagai Keterampilan Berbahasa.Bandung: Angkasa

Hamdani. 2011. Strategi Belajar Mengajar. Bandung: CV Pustaka Setia

Kemendikbud. 2016. Bahasa Indonesia.Jakarta: Kementrian Pendidikan dan Kebudayaan

Sugiyono. 2017. Metode Penelitian Pendidikan.Bandung: Alfabeta

Negeri 38 Medan Tahun Pembelajaran 2013/2014. Jurnal Pendidikan.

Sutari, dkk.1997. Menyimak. Jakarta: Depdikbud 